\title{
Sparing effect of microbial phytase on zinc supplementation in maize-soya-bean meal diets for chickens
}

\author{
C. Jondreville ${ }^{1 \dagger}$, P. Lescoat ${ }^{2}$, M. Magnin ${ }^{3}$, D. Feuerstein ${ }^{4}$, B. Gruenberg ${ }^{4}$ and Y. Nys ${ }^{2}$ \\ ${ }^{1}$ INRA, UMR1079 Systèmes d'élevage Nutrition Animale et Humaine, Agrocampus, F-35590 Saint-Gilles, France; ${ }^{2}$ INRA, UR83 Recherches Avicoles, F-37380 \\ Nouzilly, France; ${ }^{3}$ BASF Nutrition Animale, F-53200 Château Gontier, France; ${ }^{4}$ BASF AG, Rheincenter, D-67056 Ludwigshafen, Germany
}

(Received 20 November 2006; Accepted 2 April 2007)

\begin{abstract}
The experiment was conducted to evaluate the sparing effect of microbial phytase on the need for dietary zinc supplementation in chicks. A maize-soya-bean meal basal diet, containing $33 \mathrm{mg}$ of zinc and $16 \mathrm{mg}$ of copper per $\mathrm{kg}$, supplemented with 0, 6, $12,18,24,30$ or $60 \mathrm{mg}$ of zinc as sulphate per $\mathrm{kg}$ or with $250,500,750$ or 1000 units (FTU) of microbial phytase (3-phytase from Aspergillus niger, Natuphos ${ }^{\circledR}$ ) per $\mathrm{kg}$ was given to 1-day-old chicks for 20 days. Sixteen chicks placed in individual cages were assigned to each diet except the unsupplemented basal diet which was assigned to 32 cages. Actual range of phytase supplementation was 280 to 850 FTU per kg diet. Growth performance was not affected by microbial phytase. Chicks given the unsupplemented basal diet and the basal diet supplemented with $60 \mathrm{mg}$ of zinc per $\mathrm{kg}$ displayed similar performance. Bone weight, bone ash, liver weight and liver dry matter were independent $(\mathrm{P}>0.1)$ of zinc and phytase supplementations. Plasma, bone and liver zinc concentrations increased linearly $(\mathrm{P}<0.001)$ and quadratically $(\mathrm{P}<0.001 ; \mathrm{P}<0.001$ and $\mathrm{P}<0.05$, respectively) with zinc added. Plasma zinc tended to increase linearly $(\mathbb{P}=0.07)$ and bone zinc increased linearly $(\mathbb{P}<0.01)$ with phytase added but no quadratic response was detected $(\mathrm{P}>0.1)$. Liver zinc was unresponsive to phytase added $(\mathrm{P}>0.1)$. Liver copper decreased linearly $(\mathbb{P}<0.001)$ and quadratically $(\mathbb{P}<0.01)$ with zinc supplementation. Mathematical functions were fitted to the responses of plasma and bone zinc to zinc and phytase added and used to calculate zinc equivalency values of phytase. The models included a linear plateau response to zinc added and a linear response to phytase added. In diets without phytase, plasma and bone zinc concentrations were maximised for a dietary zinc concentration of $55 \mathrm{and} 51 \mathrm{mg} / \mathrm{kg}$, respectively. Over the range of 280 to $850 \mathrm{FTU}, 100 \mathrm{FTU}$ was equivalent to $1 \mathrm{mg}$ of zinc as sulphate. Consequently, in a maize-soya-bean meal chicken diet formulated to contain $60 \mathrm{mg}$ zinc per $\mathrm{kg}$, zinc ingested, and in turn, zinc excreted may be reduced by around $10 \%$ if the diet contains 500 FTU as Natuphos ${ }^{\circledR}$ per $\mathrm{kg}$.
\end{abstract}

Keywords: chickens, microbial phytase, zinc

\section{Introduction}

Phytate is widely distributed in plants for which it is the main storage form of phosphorus. This component forms insoluble complexes with zinc and limits its availability to non-ruminant species (O'Dell and Savage, 1960). Consequently, besides the excessive excretion of phosphorus, the presence of high amounts of phytates in animal diets may cause environmental pollution due to zinc accumulation in soils (Mohanna and Nys, 1999a; Burrell et al., 2004). Microbial phytase, which hydrolyses phytate, is an important means for environmental protection with regard to phosphorus excretion by both pigs and poultry

\footnotetext{
${ }^{\dagger}$ E-mail: catherine.jondreville@ensaia.inpl-nancy. Present address: INRA, USC340 Animal et Fonctionnalités des Produits Animaux, INPL-ENSAIA, BP 172, F-54505 Vandoeuvre-les-Nancy, France.
}

(Kornegay, 2001). Jondreville et al. (2005) reported that this enzyme efficiently improves zinc availability in pigs and estimated that $500 \mathrm{FTU}$ is equivalent to $30 \mathrm{mg}$ of zinc as sulphate. Moreover, in accordance with the response of phosphorus availability to pigs and broilers (Kornegay, 2001), Jondreville et al. (2005) observed a greater magnitude of the response of zinc availability to dietary phytase per unit of phytase at lowest levels of supplementation. In chicks, lower improvements in zinc availability could be achieved by incorporating microbial phytase in maizesoya-bean meal diets without mineral zinc (Biehl et al., 1995; Yi et al., 1996; Mohanna and Nys, 1999b). Yi et al. (1996) reported a linear response of zinc utilisation to microbial phytase up to 600 FTU per $\mathrm{kg}$ diet, while the results by Biehl et al. (1995) suggest a non-linear response up to 1200 FTU per kg diet. 
European regulations recently moved to a drastic reduction of maximal zinc concentration authorised in animals diets from 250 to $150 \mathrm{mg} / \mathrm{kg}$ (European Commity, 2003). Such a reduction of safety margins requires improvements in dietary zinc utilisation by animals. Because microbial phytase is widely used in broilers' diets, the sparing effect of this enzyme on the need for zinc supplementation is worth of being accurately established. Therefore, the present study was carried out to investigate the interest of adding graded levels of microbial phytase to a maize-soyabean meal diet on zinc utilisation by chickens and to calculate zinc equivalency values of phytase up to $1000 \mathrm{FTU}$ per $\mathrm{kg}$ diet. In addition, because of the negative effect of zinc on copper availability (Cousins, 1985), the effect of microbial phytase on the utilisation of dietary copper was assessed.

\section{Material and methods}

\section{Experimental diets}

A basal maize-soya-bean meal diet, containing $33 \mathrm{mg}$ of zinc per $\mathrm{kg}$, was formulated to meet all nutrient requirements of chickens from hatching to 3 weeks of age (Institut National de la Recherche Agronomique, 1989) (Table 1). In addition to the basal diet, 10 other experimental diets were obtained by supplementing the basal diet with $6,12,18$, 24,30 or $60 \mathrm{mg}$ of zinc as sulphate per $\mathrm{kg}$ (feed grade, $\mathrm{ZnSO}_{4} \cdot 7 \mathrm{H}_{2} \mathrm{O}, 321 \mathrm{mg}$ zinc per g) or with $250,500,750$ or 1000 FTU per kg (Natuphos ${ }^{\circledR}$, produced by recombinant Aspergillus niger, BASF AG, Ludwigshafen, Germany,
6450 FTU per g). Zinc sulphate has been used as a reference in many studies dealing with the evaluation of zinc availability in different organic and inorganic sources of zinc for pigs and poultry (Jongbloed et al., 2002). When phytase was added to the diet, the levels of incorporation of monodicalcium phosphate and calcium carbonate were adjusted accounting to $0.16 \mathrm{~g}$ available phosphorus and $0.20 \mathrm{~g}$ total calcium per $100 \mathrm{FTU}$ for levels of incorporation below $500 \mathrm{FTU}$ per $\mathrm{kg}$, and $0.08 \mathrm{~g}$ available phosphorus and $0.10 \mathrm{~g}$ total calcium per 100 additional FTU thereafter (Kornegay, 2001). Zinc sulphate, microbial phytase and calcium carbonate were incorporated at the expense of monodicalcium phosphate and maize starch. Feedstuffs were ground in a hammer mill fitted with a $2.5-\mathrm{mm}$ screen prior to incorporation in the diets. Diets were presented as pellets. During feed processing, temperature was not allowed to exceed $50^{\circ} \mathrm{C}$ in order to avoid any damage to dietary phytase.

\section{Animals, experimental procedures and analyses}

The experiment was conducted under the guidelines of the French Ministry of Agriculture for Animal Research. From hatching till 2 days of age, 240 male Ross white chicks were fed a standard diet covering all nutrient requirements, including zinc. On day 2, chicks were individually weighed and the 192 chicks closest to the mean weight of $59.0 \pm 3.57 \mathrm{~g}$ were blocked according to weight (16 blocks with 12 chicks). They were raised in individual plasticcoated cages and given the experimental diets for the subsequent 20-day period. In each block, each diet was

Table 1 Composition and chemical composition of the basal diet (as-fed basis)

\begin{tabular}{|c|c|c|c|}
\hline Ingredients & $\mathrm{g} / \mathrm{kg}$ & Analytical characterisation & \\
\hline Maize & 514.70 & $\mathrm{DM}(\mathrm{g} / \mathrm{kg})^{\S}$ & 882 \\
\hline Soya-bean meal & 317.71 & $\mathrm{CP}(\mathrm{N} \times 6.25, \mathrm{~g} / \mathrm{kg})^{\top}$ & 259 \\
\hline Isolated soya-bean protein & 75.00 & Ash $(g / k g)^{\S}$ & 61.2 \\
\hline Sunflower oil & 45.00 & Crude fibre $(\mathrm{g} / \mathrm{kg})^{\top}$ & 32.8 \\
\hline DL-methionine & 2.30 & Crude fat $(\mathrm{g} / \mathrm{kg})^{\sigma^{\prime}}$ & 71.3 \\
\hline $\mathrm{NaCl}$ & 3.00 & Metabolisable energy (EMan, MJ/kg) & 12.7 \\
\hline Maize starch & 0.19 & $\mathrm{Ca}(\mathrm{g} / \mathrm{kg})^{\S}$ & 9.9 \\
\hline Calcium carbonate $^{\dagger}$ & 13.10 & $P(g / k g)^{\S}$ & 7.6 \\
\hline Monodicalcium phosphate $^{\dagger}$ & 23.50 & Phytic $P(g / k g)^{\top}$ & 2.4 \\
\hline Coccidiostats & 0.50 & Available $P(\mathrm{~g} / \mathrm{kg})$ & 4.2 \\
\hline \multirow[t]{3}{*}{ Vitamin-trace mineral mix ${ }^{\ddagger}$} & 5.00 & Phytase activity (FTU per $\mathrm{kg})^{\S}$ & 40 \\
\hline & & $\mathrm{Zn}(\mathrm{mg} / \mathrm{kg})^{\S}$ & 33 \\
\hline & & $\mathrm{Cu}(\mathrm{mg} / \mathrm{kg})^{\S}$ & 16 \\
\hline
\end{tabular}

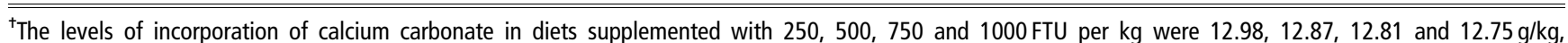
respectively; the levels of incorporation of monodicalcium phosphate $(181 \mathrm{~g} \mathrm{Ca}, 196 \mathrm{~g} \mathrm{P}$ per $\mathrm{kg}$ ) were 20.95, 18.40, 17.12 and $15.85 \mathrm{~g} / \mathrm{kg}$, respectively.

${ }^{\ddagger} Z \mathrm{n}$-free vitamin-trace mineral mix that provided the following per kilogram of diet: vitamin A, $10000 \mathrm{IU}$; vitamin D3, 2000 IU; vitamin E, $30 \mathrm{mg}$; vitamin K3 (menadione), $2 \mathrm{mg}$; vitamin B1 (thiamin), $1.5 \mathrm{mg}$; vitamin B2 (riboflavin), $4 \mathrm{mg}$; vitamin B3 (PP, niacin), $30 \mathrm{mg}$; vitamin B5 (Ca pantothenate), $10 \mathrm{mg} ;$ vitamin B6 (pyridoxine), $2.5 \mathrm{mg}$; vitamin B8 (biotin, H), $0.2 \mathrm{mg}$; vitamin B9 (folic acid), $0.4 \mathrm{mg}$; vitamin B12 (cyanocobalamin), $0.015 \mathrm{mg}$; choline, $500 \mathrm{mg} ; \mathrm{Fe}\left(\mathrm{FeSO}{ }_{4}\right.$ ), $50 \mathrm{mg}$; $\mathrm{Cu}\left(\mathrm{CuSO}_{4}\right), 10 \mathrm{mg} ; \mathrm{Mn}(\mathrm{MnO}), 85 \mathrm{mg}$; $\mathrm{Co}\left(\mathrm{CoSO}_{4}\right), 0.6 \mathrm{mg}$; I $\left(\mathrm{Ca}\left(\mathrm{IO}_{3}\right)_{2}\right), 1 \mathrm{mg} ; \mathrm{Se}\left(\mathrm{Na}_{2} \mathrm{SeO}_{3}\right), 0.25 \mathrm{mg}$.

${ }^{\S}$ Analysed as described in the Material and methods section. In diets supplemented with 250, 500, 750 and $1000 \mathrm{FTU}$ per kg, Ca concentration was 9.5, 7.9, 7.8 and $7.4 \mathrm{~g} / \mathrm{kg}$, respectively; P concentration was $7.6,6.7,6.5$ and $6.3 \mathrm{~g} / \mathrm{kg}$, respectively; phytase activity was $320,430,700$ and $390 \mathrm{FTU}$ per $\mathrm{kg}$. In diets supplemented with $6,12,18,24,30$ and $60 \mathrm{mg}$ zinc as sulphate zinc concentration was $39,45,50,55,63$ and $94 \mathrm{mg} / \mathrm{kg}$, respectively.

Calculated from Institut National de la Recherche Agronomique - Association Française de Zootechnie (2004).

Abbreviations are: $\mathrm{CP}=$ crude protein; $\mathrm{DM}=$ dry matter. 
randomly assigned to one chick, except the basal diet which was given to two birds. Twice as many chickens $(n=32)$ were thus assigned to the basal diet in order to provide a good baseline. The initial room temperature of $33^{\circ} \mathrm{C}$ was gradually decreased down to $26^{\circ} \mathrm{C}$. During the first 2 days, birds were kept under $24 \mathrm{~h}$ light the first day and $23 \mathrm{~h}$ light the day after. Birds had free access to water analysed to contain less than $0.7 \mathrm{mg}$ of zinc per I throughout the experiment. Individual feed consumption was recorded for the 20-day experimental period.

At the end of the experimental period, after an overnight fast, each chick was bled by means of heparinised tubes, weighed and then slaughtered by nembutal injection. Right tibiotarsi and liver were collected. Blood was centrifuged $\left(3000 \times \mathbf{g}, 10 \mathrm{~min}, 4^{\circ} \mathrm{C}\right)$ and plasma was stored at $-20^{\circ} \mathrm{C}$. Liver was weighed, coarsely cut, freeze-dried, ground in a blender and stored at $4^{\circ} \mathrm{C}$. Right tibiotarsi was autoclaved at $120^{\circ} \mathrm{C}$ for $20 \mathrm{~min}$, cleaned of soft tissue and frozen at $-20^{\circ} \mathrm{C}$.

All the analyses were performed in duplicate. Dry matter (DM) was determined by drying to constant weight at $103^{\circ} \mathrm{C}$. One $\mathrm{ml}$ of plasma, mixed with $0.5 \mathrm{ml}$ of $\mathrm{HCl} 3 \mathrm{~mol} / \mathrm{l}$ and $0.5 \mathrm{ml}$ of $40 \%$ trichloracetic acid, was centrifuged at $3000 \times \mathbf{g}$ for $15 \mathrm{~min}$. The supernatant was collected and diluted in $3 \mathrm{ml}$ of deionised water. The bone was longitudinally sectioned, dried at $103^{\circ} \mathrm{C}$ overnight and weighed. The whole bone was ashed at $550^{\circ} \mathrm{C}$ for $12 \mathrm{~h}$ in a muffle furnace and the obtained ash was finely ground. Samples of diets and lyophilised liver were ashed at $550^{\circ} \mathrm{C}$ for $8 \mathrm{~h}$ in a muffle furnace. Bone, diet and liver ashes were solubilised with $16 \mathrm{~mol} / / \mathrm{HNO}_{3}$ and $30 \% \mathrm{H}_{2} \mathrm{O}_{2}$ on a digestion block until dry and diluted in $0.4 \mathrm{~mol} / \mathrm{l} \mathrm{HNO}_{3}$.

Analyses of minerals except phosphorus were performed by flame atomic absorption spectrophotometry (SpectrAA 220 FS, Varian, Springvale, Australia). Phosphorus was analysed by means of the Vanadate colorimetric method using a Cobas Mira apparatus (Hoffman-LaRoche, Nutley, NJ, USA).

Phytase activity in the basal diet and in the four diets supplemented with phytase was measured colorimetrically after incubation in a sodium phytate solution (Engelen et al., 1994). One phytase unit is the amount of enzyme that liberates $1 \mu \mathrm{mol}$ of inorganic phosphorus from $5.1 \mathrm{mmol} / \mathrm{l}$ solution of sodium phytate per minute, at pH 5.5 and $37^{\circ} \mathrm{C}$.

\section{Statistical analysis}

Statistical analysis of data was performed by means of the GLM procedure of the Statistical Analysis Systems Institute (SAS, 2000) as a complete-block design and using the individual chicken as experimental unit. A one-way analysis of covariance was performed on the indicators of growth performance (feed intake, weight gain, feed conversion ratio $(F C R)$ ) and of zinc status (plasma, bone and liver zinc) according to the following model:

$$
Y_{i j}=B_{i}+\alpha \mathrm{Zn}_{i j}+\beta \mathrm{Zn}_{i j} \mathrm{Zn}_{i j}+\gamma \text { Phyt }_{i j}+\delta \text { Phyt }_{i j} \text { Phyt }_{i j}+\varepsilon_{i j} \text {, }
$$

where $Y_{i j}=$ response measurement for block $i$ and chick $j$ $(j=1,2, \ldots, 12), B_{i}=$ block effect $(i=1,2, \ldots 16), \mathrm{Zn}_{i j}=$ zinc added as sulphate in diet given to chick $j$ in block $i(\mathrm{mg} /$ $\mathrm{kg}$ diet); Phyt = microbial phytase added in diet given to chick $j$ in block $i$ (FTU per kg diet) and $\varepsilon_{i j}=$ residual error. This analysis was used to detect linear and quadratic effects of zinc and of phytase added to the diets. In this analysis of covariance, zinc and microbial phytase added were calculated from analysed and not scheduled dietary zinc concentrations and phytase activities. Differences were considered significant when $P<0.05$ and trends were noted when $P<0.10$.

Linear plateau models were fitted to the response of plasma and bone zinc concentrations to dietary supplemental zinc, either added as sulphate or released by phytase, by means of the non-linear (NLIN) procedure of SAS (2000). Linear plateau models were previously used to assess dietary zinc required for maximum plasma and bone zinc concentration in piglets (Jondreville et al., 2005; Revy et al., 2006) and in chicks (Wedekind et al., 1992). The models were of the following form:

If supplemental zinc $<a, \quad Y=c+b \quad$ (supplemental zinc $-a) ;$ if supplemental zinc $\geqslant a, \quad Y=c$, with $Y=$ response measurement, supplemental zinc $=$ zinc added as sulphate or released by microbial phytase ( $\mathrm{mg} / \mathrm{kg}$ diet), $a=$ breakpoint, $b=$ slope of the response when supplemental zinc $<a, c=$ maximum value of $Y$.

Supplemental zinc was written as the sum of zinc added as sulphate and as a function of phytase added. This function is the equation used to estimate equivalency values of phytase for zinc. Its form (linear or curvilinear) was chosen according to the results of the analysis of covariance previously performed. If the response of indicators of zinc status to phytase was linear, with no quadratic effect, then the equivalency of phytase for zinc as sulphate was considered as directly proportional to phytase. Thus, the model was as follows:

If $\mathrm{Zn}+d$ Phyt $<a, \quad Y=c+b(\mathrm{Zn}+d$ Phyt $-a) ;$ if $\mathrm{Zn}+$ $d$ Phyt $\geqslant a, Y=c$, with $Y=$ response measurement, $Z n=$ zinc added as sulphate (mg $/ \mathrm{kg}$ diet); Phyt $=$ microbial phytase (FTU per kg diet), $a=$ breakpoint, $b=$ slope of the response, $c=$ maximum value of $Y, d=$ equivalency of one unit of phytase for zinc (mg zinc per FTU).

Linear plateau models were adjusted using treatment means. Zinc and microbial phytase were calculated from analysed dietary zinc concentrations and phytase activities. The coefficient of determination $\left(R^{2}\right)$ of each generated equation was calculated as the square of the correlation coefficient between predicted and observed individual values. The root mean square error (r.m.s.e.) is the root square of the sum of squares of differences between predicted and observed individual values divided by the number of observations.

Meta-analyses of literature data were performed in order to (1) evaluate dietary zinc required for maximum plasma and bone zinc concentrations in chicks and (2) estimate equivalencies of microbial phytase for zinc as sulphate. In 
the reported experiments, plasma and bone zinc concentrations were recorded in chicks given plant feedstuffsbased diets added with graded levels of zinc as sulphate or microbial phytase. For the first meta-analysis, only dietary treatments without phytase were kept, whereas for the second, experiments in which diets without and with phytase were compared were considered. Experiments started and ended 0 to 5 and 16 to 35 days after hatching, respectively. Linear plateau models similar to those previously described were adjusted using treatment means. For the second meta-analysis, the equivalency of phytase for zinc as sulphate was considered as directly proportional to phytase activity, as previously described. To account for the variability between experiments, the parameter $c$ (maximum value of the response parameter) was adjusted within experiments. The breakpoint $a$, the slope $b$ and the equivalency of one unit of phytase for zinc $d$ were adjusted between experiments. Since the number of replicates per treatment was very similar between experiments, this parameter was not introduced in the model. $R^{2}$ and r.m.s.e were calculated as described above.

\section{Results}

Dietary zinc analyses show that $6,12,17,22,30$ and $61 \mathrm{mg}$ zinc were added per $\mathrm{kg}$ diet, in accordance with the scheduled $6,12,18,24,30$ and $60 \mathrm{mg}$ zinc per $\mathrm{kg}$, respectively (Table 2). As expected, the basal diet was devoid of significant phytase activity (40 FTU per $\mathrm{kg}$ ). However, the range of microbial phytase addition to the basal diet was narrower than expected with 280, 390, 660 and 850 FTU per kg instead of 250, 500, 750 and 1000 FTU per $\mathrm{kg}$.

Six birds died before the end of the experiment or displayed abnormal legs at slaughter and were removed from the data set. At the end, at least 14 replicates were available for each experimental treatment.

\section{Growth performance and plasma, bone and liver characteristics}

Results are presented in Table 2. Feed intake, weight gain and FCR were independent of the presence of phytase in the diet $(P>0.1)$. Compared with chickens fed the unsupplemented basal diet, chickens fed the diets with 12 and 30 p.p.m. of zinc added as sulphate displayed a higher weight gain. These differences led to a linear $(P<0.05)$ and quadratic $(P<0.05)$ response of weight gain to zinc added. Feed intake and FCR were independent of dietary zinc $(P>0.1)$.

Plasma zinc concentration increased linearly and quadratically $(P<0.001)$ with zinc added and tended to increase linearly $(P=0.07)$ with phytase. Bone weight and bone ash were independent of the dietary levels of zinc and of microbial phytase $(P>0.1)$. Bone zinc expressed as $\mathrm{mg} / \mathrm{kg}$ ash or as $\mathrm{mg} / \mathrm{kg}$ DM increased linearly and quadratically $(P<0.001)$ with zinc and increased linearly $(P<0.001$;
$P<0.01$, respectively) with phytase. Birds given the diet supplemented with the highest level of phytase displayed lower plasma and bone zinc concentrations than birds on the diet supplemented with $60 \mathrm{mg}$ zinc per $\mathrm{kg}(-21 \%$ for plasma zinc and $-26 \%$ for bone zinc). Liver weight and DM concentration were independent of dietary zinc and phytase $(P>0.1)$. Liver zinc concentration increased linearly $(P<0.001)$ and quadratically $(P<0.05)$ with zinc added. On the contrary, liver copper concentration decreased linearly $(P<0.001)$ and quadratically $(P<0.05)$ with dietary zinc. Liver content of these two elements was independent of microbial phytase $(P>0.1)$.

\section{Models of the response of indicators of zinc status to graded levels of zinc and phytase and equivalency values of zinc added as sulphate for microbial phytase}

Parameters of linear plateau models generated for the response of plasma and bone zinc to supplemental zinc either added as sulphate or released by microbial phytase are presented in Table 3. Because the previous covariance analysis revealed that plasma and bone zinc increased linearly and not quadratically when phytase was added, the equivalency of phytase for zinc as sulphate was considered as directly proportional to phytase. Coefficients of determination were 0.52 for plasma zinc concentration and 0.76 to 0.79 for bone zinc concentration. These criteria linearly increased until supplemental zinc reached 22.3, 17.8 and $18.5 \mathrm{mg} / \mathrm{kg}$ diet, respectively, and reached a plateau at $2.13 \mathrm{mg}$ zinc per I plasma, $185 \mathrm{mg}$ zinc per $\mathrm{kg}$ bone DM and $376 \mathrm{mg}$ zinc per $\mathrm{kg}$ bone ash.

Equivalency values of zinc as sulphate for microbial phytase are presented in Table 4 . The response of the indicators of zinc status to phytase added being linear, these equivalencies also increased linearly between 280 and $850 \mathrm{FTU}$, by 1.1 and $0.9 \mathrm{mg}$ zinc per $100 \mathrm{FTU}$ for plasma and bone zinc, respectively.

\section{Discussion}

In the current study, growth performance was not affected by microbial phytase. Chicks given the basal diet supplemented with $12 \mathrm{mg}$ zinc per $\mathrm{kg}$ displayed higher weight gain than those given the unsupplemented basal diet, but additional supply of zinc had no further effect in contrast to what was observed for blood or bone zinc concentrations. National Research Council (1994) states that the provision of diets containing $40 \mathrm{mg}$ of zinc per $\mathrm{kg}$ is optimal for chick growth. However, in previous studies, no improvement in growth performance of chicks up to 21 days of age was observed by adding zinc (Mohanna and Nys, 1999b; Burrell et al., 2004; Jondreville et al., 2007) or microbial phytase (Mohanna and Nys, 1999b; Jondreville et al., 2007) to maize-soya-bean meal diets not supplemented with zinc, containing at least $28 \mathrm{mg}$ of zinc per $\mathrm{kg}$. In contrast, improvements in weight gain (Yi et al., 1996; Mohanna and Nys, 1999a) and in FCR (Mohanna and Nys, 1999a) were 
Table 2 Growth performance and plasma, bone and liver characteristics of chickens given the basal diet supplemented with zinc as sulphate or microbial phytase

\begin{tabular}{|c|c|c|c|c|c|c|c|c|c|c|c|c|c|c|c|c|}
\hline \multirow{3}{*}{$\begin{array}{l}\mathrm{Zn} \text { added }(\mathrm{mg} / \mathrm{kg} \text { diet) } \\
\text { Microbial phytase (FTU per kg diet) })^{\ddagger}\end{array}$} & \multirow{3}{*}{$\begin{array}{l}0 \\
0\end{array}$} & \multirow{3}{*}{$\begin{array}{l}6 \\
0\end{array}$} & \multirow{3}{*}{$\begin{array}{c}12 \\
0\end{array}$} & \multirow{3}{*}{$\begin{array}{c}17 \\
0\end{array}$} & \multirow{3}{*}{$\begin{array}{c}22 \\
0\end{array}$} & \multirow{3}{*}{$\begin{array}{c}30 \\
0\end{array}$} & \multirow{3}{*}{$\begin{array}{c}61 \\
0\end{array}$} & \multirow{3}{*}{$\begin{array}{c}0 \\
280\end{array}$} & \multirow{3}{*}{$\begin{array}{c}0 \\
390\end{array}$} & \multirow{3}{*}{$\begin{array}{c}0 \\
660\end{array}$} & \multirow{3}{*}{$\begin{array}{c}0 \\
850\end{array}$} & \multicolumn{5}{|c|}{ Significance $^{+}$} \\
\hline & & & & & & & & & & & & \multicolumn{2}{|c|}{ Zn added } & \multicolumn{3}{|c|}{ Microbial phytase } \\
\hline & & & & & & & & & & & & $\mathrm{L}$ & Q & $\mathrm{L}$ & Q & r.m.s.e $e^{\dagger}$ \\
\hline No. & 30 & 16 & 15 & 16 & 16 & 14 & 16 & 16 & 16 & 15 & 16 & & & & & \\
\hline Initial weight (day 2) (g) & 59.2 & 59.1 & 58.7 & 58.8 & 58.9 & 59.1 & 58.9 & 58.9 & 59.0 & 58.5 & 59.3 & NS & NS & NS & NS & 3.66 \\
\hline Final weight $(\mathrm{g})^{\S}$ & 922 & 932 & 997 & 956 & 929 & 982 & 936 & 953 & 967 & 943 & 942 & * & * & NS & NS & 85.2 \\
\hline Weight gain $(g)^{\S}$ & 863 & 873 & 938 & 898 & 870 & 923 & 877 & 894 & 908 & 885 & 883 & * & * & 0.09 & NS & 84.2 \\
\hline Feed intake (g) & 1089 & 1104 & 1164 & 1130 & 1082 & 1155 & 1095 & 1140 & 1131 & 1108 & 1105 & NS & NS & NS & NS & 107.5 \\
\hline Feed conversion ratio & 1.26 & 1.27 & 1.24 & 1.26 & 1.24 & 1.25 & 1.25 & 1.28 & 1.25 & 1.26 & 1.25 & NS & NS & NS & NS & 0.059 \\
\hline Plasma Zn $(\mathrm{mg} /)^{\S}$ & 1.31 & 1.65 & 1.77 & 1.89 & 2.11 & 2.13 & 2.13 & 1.39 & 1.47 & 1.59 & 1.69 & $* * *$ & *** & 0.07 & NS & 0.265 \\
\hline Bone weight (g) & 3.69 & 3.54 & 3.84 & 3.60 & 3.65 & 3.80 & 3.61 & 3.59 & 3.48 & 3.70 & 3.74 & NS & NS & NS & NS & 0.518 \\
\hline Bone ash (g/kg DM) & 495 & 503 & 507 & 498 & 492 & 501 & 489 & 498 & 491 & 486 & 496 & NS & NS & NS & NS & 25.2 \\
\hline Bone Zn (mg/kg ash) ${ }^{\S}$ & 204 & 273 & 328 & 356 & 367 & 373 & 386 & 231 & 251 & 265 & 281 & $* * *$ & $* * *$ & $* * *$ & NS & 33.3 \\
\hline Bone $\mathrm{Zn}(\mathrm{mg} / \mathrm{kg} \mathrm{DM})^{\S}$ & 101 & 137 & 166 & 177 & 181 & 187 & 189 & 115 & 123 & 129 & 140 & $* * *$ & $* * *$ & ** & NS & 17.6 \\
\hline Liver weight (g) & 22.5 & 22.4 & 24.3 & 22.3 & 22.3 & 23.7 & 22.1 & 22.5 & 23.7 & 22.7 & 22.3 & NS & NS & NS & NS & 2.97 \\
\hline Liver DM (g/kg) & 251 & 252 & 257 & 255 & 252 & 260 & 257 & 253 & 250 & 251 & 254 & NS & NS & NS & NS & 13.5 \\
\hline Liver Zn (mg/kg DM) ${ }^{\S}$ & 80.6 & 88.7 & 86.6 & 89.6 & 91.0 & 88.7 & 93.4 & 80.7 & 83.4 & 83.8 & 85.7 & *** & * & NS & NS & 8.26 \\
\hline Liver Cu (mg/kg DM) $)^{\S}$ & 22.6 & 17.3 & 15.7 & 16.4 & 16.4 & 15.6 & 16.1 & 19.5 & 19.6 & 17.9 & 17.2 & $* * *$ & $* *$ & NS & NS & 6.06 \\
\hline
\end{tabular}

${ }^{\dagger}$ r.m.s.e. $=$ root mean square error; linear $(\mathrm{L})$ and quadratic (Q) effects of zinc added as sulphate and of microbial phytase; ${ }^{* * *} P<0.001 ;{ }^{* *} P<0.01 ;{ }^{*} P<0.05$; NS $P>0.10$.

${ }^{*}$ Calculated from analysed zinc concentration and phytase activity in diets presented in Table 1.

SEstimates of the parameters were as follows: final weight $(\mathrm{g})=941+2.36 \mathrm{Zn}-0.0321 \mathrm{Zn}^{2}, R^{2}=0,10$; weight gain $(\mathrm{g})=880+2.37 \mathrm{Zn}-0.0322 \mathrm{Zn} \mathrm{n}^{2}, R^{2}=0,10 ;$ plasma $\mathrm{Zn}(\mathrm{mg} / \mathrm{l})=1.27+0.0398 \mathrm{Zn}-0.000406$ $\mathrm{Zn}^{2}+0.000481$ Phyt, $R^{2}=0.62$; bone $\mathrm{Zn}\left(\mathrm{mg} / \mathrm{kg}\right.$ ash) $=221+8.34 \mathrm{Zn}-0.0855 \mathrm{Zn}^{2}+0.121$ Phyt, $R^{2}=0.80$; bone Zn (mg/kg DM) $=107+4.19 \mathrm{Zn}-0.0438 \mathrm{Zn}{ }^{2}+0.0539$ Phyt, $R^{2}=0.79$; Liver Zn (mg/kg DM): $89.3+0.418 \mathrm{Zn}-0.00379 \mathrm{Zn}^{2}, R^{2}=0.37$; Liver $\mathrm{Cu}(\mathrm{mg} / \mathrm{kg} \mathrm{DM})=21.1-0.337 \mathrm{Zn}+0.00381 \mathrm{Zn}^{2}, R^{2}=0,15$, with $\mathrm{Zn}=$ zinc added as sulphate (mg/kg diet); Phyt $=$ microbial phytase (FTU per kg diet).

Abbreviation is: $\mathrm{DM}=\mathrm{dry}$ matter. 
Table 3 Adjustment of plasma, bone and liver zinc concentrations to zinc added as sulphate and to microbial phytase ${ }^{t}$

\begin{tabular}{lcccccc}
\hline \hline & \multicolumn{6}{c}{ Coefficients $^{\ddagger}$} \\
\cline { 2 - 7 } & $a$ & $b$ & $c$ & $d$ & $R^{2}$ & r.m.s.e. \\
\hline Plasma Zn (mg/l) & 22.3 & 0.0363 & 2.13 & 0.0112 & 0.52 & 0.217 \\
Bone Zn (mg/kg DM) & 17.8 & 4.48 & 185 & 0.00864 & 0.76 & 15.9 \\
Bone Zn (mg/kg ash) & 18.5 & 8.86 & 376 & 0.00931 & 0.79 & 30.7 \\
\hline
\end{tabular}

${ }^{\dagger}$ Models were generated using treatment means and assayed dietary zinc concentrations and phytase activities.

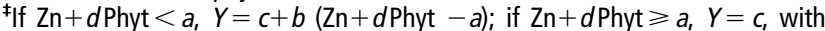
$Y=$ response measurement, $\mathrm{Zn}=$ zinc added as sulphate $(\mathrm{mg} / \mathrm{kg}$ diet); Phyt $=$ microbial phytase (FTU per kg diet), $a=$ breakpoint, $b=$ slope of the response, $c=$ maximum value of $Y, d=$ equivalency of one unit of phytase for zinc (mg zinc per FTU).

$R^{2}$, coefficient of determination calculated as the square of the correlation coefficient between predicted and observed individual values; r.m.s.e., root mean square error calculated as the root square of the sum of squares of differences between predicted and observed individual values divided by the number of observations.

Abbreviation is: $\mathrm{DM}=$ dry matter.

Table 4 Equivalency values of zinc added as sulphate (mg) for microbial phytase (FTU) generated from the response of plasma and bone zinc concentrations to zinc added as sulphate and to microbial phytase $^{t}$

\begin{tabular}{lcccc}
\hline \hline & \multicolumn{4}{c}{ Phytase activity (FTU) } \\
\cline { 2 - 5 } & 280 & 390 & 660 & 850 \\
\hline Plasma Zn (mg/l) & 3.1 & 4.4 & 7.4 & 9.5 \\
Bone Zn (mg/kg DM) & 2.4 & 3.4 & 5.7 & 7.3 \\
Bone Zn (mg/kg ash) & 2.6 & 3.6 & 6.1 & 7.9 \\
\hline \hline
\end{tabular}

${ }^{\mathrm{t}} \mathrm{Zn}=d$ Phyt, with $\mathrm{Zn}=$ zinc added as sulphate $(\mathrm{mg})$, Phyt $=$ microbial phytase (FTU), $d=0.0112,0.00864$ and $0.00931 \mathrm{mg}$ zinc per FTU for plasma zinc, bone zinc relative to bone dry matter and bone zinc relative to bone ash, respectively.

Abbreviation is: $\mathrm{DM}=$ dry matter.

achieved when the unsupplemented maize-soya-bean meal basal diet contained around $20 \mathrm{mg}$ of zinc per $\mathrm{kg}$. According to Burrell et al. (2004), improvements in growth rate could not be observed by adding zinc to a diet containing around $30 \mathrm{mg}$ zinc per $\mathrm{kg}$ because zinc provision by the basal diet was too close to the recommended allowance.

The indicators of zinc status were plasma zinc concentration, which is an indicator of functional zinc and bone and liver zinc concentrations, which are indicators of body stores of zinc. Plasma and bone zinc were previously used for assessing zinc requirements in chicks by adjusting broken-line models to their response to dietary zinc (Wedekind et al., 1992; Mohanna and Nys, 1999a). Liver zinc was shown to increase with dietary zinc in chicks (Yi et al., 1996) and in piglets (Jondreville et al., 2005).

In diets without phytase, plasma and bone zinc concentrations linearly increased until dietary zinc reached 55 and $51 \mathrm{mg} / \mathrm{kg}$ diet, respectively, and plateaued thereafter. The slope of the response was $0.0363 \mathrm{mg}$ plasma zinc per I
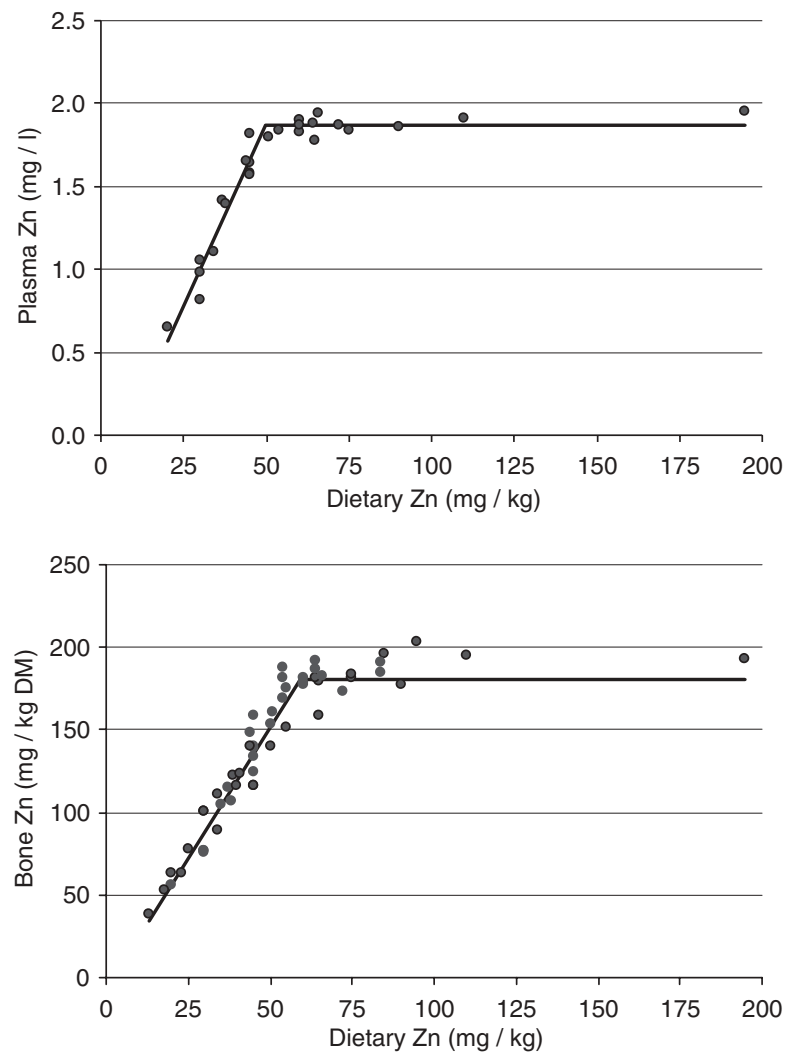

Figure 1 Response of plasma and bone zinc concentrations in chicks on diets without microbial phytase supplemented with variable amounts of zinc as sulphate - metaanalysis of literature datat. The model is if $\mathrm{Zn}<a$, $Y=c+b(\mathrm{Zn}-a)$; if $\mathrm{Zn} \geqslant a, Y=c$, with $\mathrm{Zn}=$ dietary zinc (mg/kg diet), $Y=$ response measurement, $a=$ breakpoint, $b=$ slope of the response, $c=$ maximum value of $Y$.

\begin{tabular}{lcccccccc}
\hline \hline & $a$ & $b$ & $c$ & Obs $^{\ddagger}$ & $\operatorname{Exp}^{\ddagger}$ & Ref $^{\ddagger}$ & $R^{2 \ddagger}$ & r.m.s.e. \\
\hline $\begin{array}{l}\text { Plasma Zn } \\
\text { (mg/l) }\end{array}$ & 49.9 & 0.0435 & 1.87 & 25 & 6 & 4 & 0.96 & 0.077 \\
$\begin{array}{l}\text { Bone Zn } \\
\text { (mg/kg DM) }\end{array}$ & 59.2 & 3.17 & 181 & 56 & 15 & 10 & 0.95 & 9.8 \\
\hline
\end{tabular}

'Wedekind et al., 1992; Thiel et al., 1993; Roberson and Edwards, 1994; Biehl et al., 1995; Yi et al., 1996; Mohanna and Nys, 1999a and 1999b; Mohanna et al., 1999; Swiatkiewicz et al., 2001; Jondreville et al., 2007.

${ }^{\ddagger}$ Obs = number of observations; Exp = number of experiments; Ref = number references; $R^{2}=$ coefficient of determination; r.m.s.e. $=$ root mean square error.

and $4.48 \mathrm{mg}$ zinc per $\mathrm{kg}$ bone DM for one additional $\mathrm{mg}$ of dietary zinc. In accordance with Mohanna and Nys (1999a) but at variance with Wedekind et al. (1992), we did not observe any further increase in bone zinc beyond the breakpoint. Based on literature data, we adjusted linear plateau models to plasma and bone zinc concentrations in chicks given diets without added phytase supplemented with variable amounts of zinc as sulphate (Figure 1). Results of the current experiment are in accordance with the estimates for the slopes $(0.0435 \mathrm{mg}$ zinc per I plasma and $3.17 \mathrm{mg}$ zinc per $\mathrm{kg}$ bone DM for one additional $\mathrm{mg}$ of dietary zinc) and for zinc required for maximum plasma and bone zinc concentrations ( 50 and $59 \mathrm{mg}$ zinc per $\mathrm{kg}$ diet, respectively) derived from this analysis of the literature. 
Between 0 and $24 \mathrm{mg}$ zinc per $\mathrm{kg}$ diet, liver zinc concentration increased by $0.52 \mathrm{mg} / \mathrm{mg}$ dietary zinc, which is similar to the linear increase of $0.51 \mathrm{mg}$ liver zinc per $\mathrm{mg}$ dietary zinc reported by Yi et al. (1996).

The absence of any effect of experimental diets on bone ash concentration despite the decreased dietary $\mathrm{P}$ and $\mathrm{Ca}$ concentrations concomitant to microbial phytase addition suggests that this enzyme was effective in hydrolysing phytates and improving $\mathrm{P}$ and $\mathrm{Ca}$ availability. Improvements in zinc availability by microbial phytase added to low zinc diets fed to chicks were previously reported (e.g. Thiel et al., 1993; Mohanna and Nys, 1999b; Yi et al., 1996). In some instances, no effect of microbial phytase on zinc availability could be detected because of the high zinc concentration in the experimental diets (Thiel et al., 1993; Sebastian et al., 1996; Mohanna and Nys, 1999b). In chicks, Yi et al. (1996) observed a linear response of bone and liver zinc to graded levels of phytase up to $600 \mathrm{FTU}$ per $\mathrm{kg}$ introduced in a maize-soya isolate diet. The equivalencies of 3.8 and $5.5 \mathrm{mg}$ zinc as sulphate for 600 and 1200 FTU estimated by Biehl et al. (1995) suggest a decreasing efficacy of microbial phytase per unit when the level of incorporation of phytase increases. This is in accordance with the response of $P$ availability to phytase supplementation (Kornegay, 2001). Unfortunately, in the current experiment, the maximum level of phytase supplementation reached only 850 FTU per $\mathrm{kg}$ instead of $1000 \mathrm{FTU}$ per $\mathrm{kg}$ expected. Within this range of phytase supplementation, the response of plasma and bone zinc remained linear. One mg of zinc as sulphate could be replaced per 100 FTU over the range of 280 to 850 FTU. This equivalency is in agreement with the estimate of $0.9 \mathrm{mg}$ zinc as sulphate for $100 \mathrm{FTU}$ up to $600 \mathrm{FTU}$ per $\mathrm{kg}$ diet by $\mathrm{Yi}_{\mathrm{i}}$ et al. (1996). Based on literature data, we adjusted linear plateau models to the response of plasma and bone zinc to dietary zinc in diets containing different levels of microbial phytase (Figure 2). From this data set, no curvilinear response to phytase added could be detected; therefore, the release of zinc was considered as proportional to microbial phytase up to $1200 \mathrm{FTU}$. This proportionality may explain the slightly lower equivalency of $0.7 \mathrm{mg}$ zinc as sulphate for 100 FTU derived from this literature review.

These equivalencies in chicks are far below the estimates of $30 \mathrm{mg}$ zinc as sulphate for $500 \mathrm{FTU}$ in piglets (Jondreville et al., 2005; Revy et al., 2006). Moreover, over a range of 150 to $850 \mathrm{FTU}$ introduced per $\mathrm{kg}$ of a maize-soya-bean meal diet, Jondreville et al. (2005) calculated that the release of zinc from phytates by phytase was not linear but proportional to the one of phosphorus. The results of a recent study conducted in our laboratory (Jondreville et al., 2007) suggest that the low pH in gizzard allows zincphytates complex to dissociate, even in the absence of phytase, whereas, in stomach of piglets, where the $\mathrm{pH}$ is higher, phytates must be hydrolysed by phytase before zinc can be released as soluble zinc. This phenomenon would result in a physiologically higher availability of zinc in chickens than in piglets, explaining the lower dietary

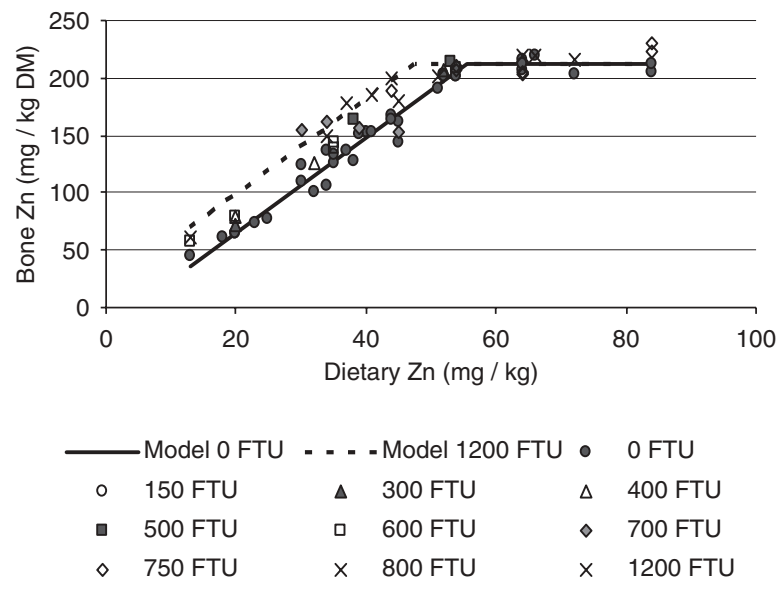

Figure 2 Response of bone zinc in chickens to graded levels of zinc as sulphate and of microbial phytase - metanalysis of literature datat. The model is: if $\mathrm{Zn}+d$ Phyt $<a, Y=c+b(\mathrm{Zn}+d$ Phyt $-a)$; if $\mathrm{Zn}+d$ Phyt $\geqslant$ $a, Y=c$, with $\mathrm{Zn}=$ dietary zinc ( $\mathrm{mg} / \mathrm{kg}$ diet), Phyt = dietary phytase (FTU per kg diet), $Y=$ response measurement, $a=$ breakpoint, $b=$ slope of the response, $c=$ maximum value of $Y, d=$ equivalency of one unit of phytase for zinc (mg zinc per FTU).

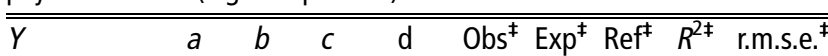

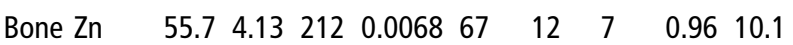

(mg/kg DM)

${ }^{\dagger}$ Thiel et al., 1993; Roberson and Edwards, 1994; Biehl et al., 1995; Yi et al., 1996; Mohanna and Nys, 1999b; Swiatkiewicz et al., 2001; Jondreville et al., 2007.

${ }^{\ddagger}$ Obs = number of observations; Exp $=$ number of experiments; Ref $=$ number references; $R^{2}=$ coefficient of determination; r.m.s.e. $=$ root mean square error.

requirements of birds than piglets for this element (50 to $60 \mathrm{mg}$ zinc per $\mathrm{kg}$ of a maize-soya-bean meal based diet for a maximum plasma and bone zinc concentrations in chicks according to the current study v. 85 to $90 \mathrm{mg}$ zinc per $\mathrm{kg}$ diet in piglets according to Jondreville et al. (2005) and Revy et al. (2006)). It would also explain the differential efficacy of phytase for improved zinc availability in chickens and in piglets.

It was calculated that zinc excretion by piglets could be reduced by $30 \%$ by replacing $30 \mathrm{mg}$ of zinc as sulphate by 500 FTU microbial phytase in a maize-soya-bean meal diet formulated to contain $100 \mathrm{mg}$ zinc per $\mathrm{kg}$ (Jondreville et al., 2005). According to the current results, a chicken diet without microbial phytase containing $60 \mathrm{mg}$ zinc per $\mathrm{kg}$ would result in similar performance and zinc retention than a diet containing 500 FTU microbial phytase and $55 \mathrm{mg}$ zinc per $\mathrm{kg}$. Considering a FCR of 1.25 , a body-weight gain of $1000 \mathrm{~g}$ per bird and a zinc retention of $20 \mathrm{mg} / \mathrm{kg}$ body weight (Mohanna and Nys, 1999a), this reduction of zinc ingested from 75 to $69 \mathrm{mg} / \mathrm{bird}$, would result in a similar zinc retention of $20 \mathrm{mg}$ per bird and consequently to a reduction of zinc excreted by $11 \%$ ( 55 v. $49 \mathrm{mg}$ per bird).

Liver copper concentration decreased by $30 \%$ when $12 \mathrm{mg}$ of zinc were added to the basal diet and remained steady thereafter. Although not significant because of a 
high variability within treatments, a negative effect of microbial phytase on liver copper concentration was also recorded. Decreased liver copper accompanying increased dietary zinc was previously reported in piglets (Zacharias et al., 2003; Revy et al., 2004) and was interpreted as a result of the negative effect of zinc on copper availability (Cousins, 1985). In piglets, Zacharias et al. (2003) reported an indirect impairment of copper status by phytase and suggested it was due to the release of zinc by phytase. However, the studies by Jondreville et al. (2005) and Revy et al. (2006) did not corroborate this hypothesis. On the contrary, a positive effect of phytase on copper balance was reported in piglets (Adeola et al., 1995; Revy et al., 2004) and in chickens (Sebastian et al., 1996) and was interpreted as an overall positive effect of this enzyme on mineral balance. Ultimately, the possible effect of phytase on copper availability remains debatable.

The current study confirms that, in diets without microbial phytase, 55 to $60 \mathrm{mg}$ of zinc per $\mathrm{kg}$ diet are required to maximise bone and plasma zinc concentrations in chicks. Up to $850 \mathrm{FTU}$, the supplementation of $1 \mathrm{mg}$ of zinc as sulphate can be spared per 100 FTU. In a chicken diet formulated to contain $60 \mathrm{mg}$ zinc per $\mathrm{kg}$, the replacement of $5 \mathrm{mg}$ zinc per $\mathrm{kg}$ by $500 \mathrm{FTU}$ as Natuphos ${ }^{\circledR}$ would allow a reduction of zinc excreted by chickens by around $10 \%$.

\section{Acknowledgements}

The authors are grateful to Sandrine Hillion and to Anne-Marie Chagneau for their technical assistance. They also acknowledge Maryse Mills, Kléber Gérard, Jean-Marc Meslier, Frédéric Mercerand, Michel Derouet and Thierry Bordeau of the UR Recherches Avicoles of INRA at Nouzilly and Georges Guillemois, Raymond Vilboux and Patrick Touanel of the UMR Systèmes d'Elevage Nutrition et Humaine of INRA at Saint-Gilles.

\section{References}

Adeola O, Lawrence BV, Sutton AL and Cline TR 1995. Phytase-induced changes in mineral utilization in zinc-supplemented diets for pigs. Journal of Animal Science 73, 3384-3391.

Biehl R, Baker D and DeLuca H 1995. 1-alpha-hydroxylated cholecalciferol compounds act additively with microbial phytase to improve phosphorus, zinc and manganese utilization in chicks fed soy-based diets. The Journal of Nutrition 125, 2407-2416.

Burrell AL, Dozier WA, Davis AJ, Compton MM, Freeman ME, Vendrell PF and Ward TL 2004. Responses of broilers to dietary zinc concentrations and sources in relation to environmental protection. British Poultry Science 45, 255-263.

Cousins RJ 1985. Absorption, transport, and hepatic metabolism of copper and zinc: special reference to metallothionein and ceruloplasmin. Physiology Reviews 65, 238-309.

Engelen AJ, van der Heeft FC, Randsdorp PHG and Smit ELC 1994. Simple and rapid determination of phytase activity. Journal of AOAC International 77, 760-764.

European Community, 2003. Commission regulation (EC) no. 1334/2003 of 25 July 2003 amending the conditions for authorisation of a number of additives in feedingstuffs belonging to the group of trace elements. Official Journal of the European Union, 26 July 2003, L187/11-15.
Institut National de la Recherche Agronomique 1989. L'alimentation des animaux monogastriques: porc, lapin, volailles. INRA, Paris, France.

Institut National de la Recherche Agronomique - Association Française de Zootechnie 2004. Tables of composition and nutritional value of feed materials. In: Sauvant D, Perez JM and Tran G (eds.), Pigs, poultry, cattle, sheep, goats, rabbits, horses, fish. INRA - AFZ, Paris, France.

Jondreville C, Hayler R and Feuerstein D 2005. Replacement of zinc sulphate by microbial phytase for piglets fed a maize-soya-bean meal diet. Animal Science 81, 77-83.

Jondreville C, Schlegel P, Hillion H, Chagneau AM and Nys Y 2007. Effects of additional zinc and phytase on zinc availability to piglets and chicks fed diets containing different amounts of phytates. Livestock Science 109, 60-62.

Jongbloed AW, Kemme PA, De Groote G, Lippens M and Meschy F 2002. Bioavailability of major and trace minerals. EMFEMA, International Association of the European Manufacturers of Major, Trace and Specific Feed Mineral Materials, Brussels, Belgium.

Kornegay ET 2001. Digestion of phosphorus and other nutrients: the role of phytases and factors influencing their activity. In: Bedford MR and Partridge GG (eds.), Enzymes in farm animal nutrition. CAB International, Wallingford, UK, pp. 237-271.

Mohanna C and Nys Y 1999a. Effect of dietary zinc content and sources on the growth, body zinc deposition and retention, zinc excretion and immune response in chickens. British Poultry Science 40, 108-114.

Mohanna C and Nys Y 1999b. Changes in zinc and manganese availability in broiler chicks induced by vegetal and microbial phytase. Animal Feed Science and Technology 77, 241-253.

Mohanna C, Carré B and Nys Y 1999. Incidence of dietary viscosity on growth performance and zinc and manganese bioavailability in broilers. Animal Feed Science and Technology 77, 255-266.

National Research Council 1994. Nutrient requirements of poultry, 9th edition. National Academy Press, Washington, DC.

O'Dell BL and Savage JE 1960. Effect of phytic acid on zinc availability. Proceedings of the Society for Experimental Biology and Medicine 103, 304-306.

Revy PS, Jondreville C, Dourmad JY and Nys Y 2004. Effect of zinc supplemented as either an organic or an inorganic source and of microbial phytase on zinc and other minerals utilisation by weanling pigs. Animal Feed Science and Technology 116, 93-112.

Revy PS, Jondreville C, Dourmad JY and Nys Y 2006. Assessment of dietary zinc requirement of weaned piglets fed diets with or without microbial phytase. Journal of Animal Physiology and Animal Nutrition 90, 50-59.

Roberson $\mathrm{K}$ and Edwards $\mathrm{H}$ 1994. Effects of 1,25-dihydroxycholecalciferol and phytase on zinc utilization in broiler chicks. Poultry Science 73, 1312-1326.

Sebastian S, Touchburn S, Chavez ER and Lague PC 1996. The effects of supplemental microbial phytase on the performance and utilization of dietary calcium, phosphorus, copper and zinc in broiler chickens fed corn-soybean diets. Poultry Science 75, 729-736.

Statistical Analysis Systems Institute 2000. Software package version 8.1. SAS Institute, Cary, NC, USA.

Swiatkiewicz S, Koreleski J and Zhong DQ 2001. The bioavailability of zinc from inorganic and organic sources in broiler chickens as affected by addition of phytase. Journal of Animal and Feed Sciences 10, 317-328.

Thiel $U$, Weigand $E$, Hoppe $P$, and Schoner $F$ 1993. Zinc retention of broiler chickens as affected by dietary supplementation of zinc and microbial phytase. Proceedings of the Eighth International Symposium on Trace Elements in Man and Animals, Dresden, Germany, pp. 658-659.

Wedekind KJ, Hortin AE and Baker DH 1992. Methodology for assessing zinc bioavailability: efficacy estimates for zinc-methionine, zinc sulfate, and zinc oxide. Journal of Animal Science 70, 178-187.

Yi Z, Kornegay ET and Denbow DM 1996. Supplemental microbial phytase improves zinc utilisation in broilers. Poultry Science 75, 540-546.

Zacharias B, Ott H and Drochner W 2003. The influence of dietary microbial phytase and copper on copper status in growing pigs. Animal Feed Science and Technology 106, 139-148. 